\title{
“YOUTH CREATIVE ENTERPRENEUR EMPOWERMENT (YOUTIVEE)": Solusi bagi Kaum Muda untuk Berkontribusi pada Perekonomian dan Mengurangi Pengangguran.
}

\author{
Studi Kasus Mahasiswa Univeristas Islam Lamongan
}

\author{
Muhamad Imam Syairozi \\ Program Studi Manajemen Fakultas Ekonomi \\ Universitas Islam Lamongan \\ imamsyairozi87@gmail.com
}

\section{Anim Fattah}

Program Studi Manajemen Fakultas Ekonomi

Universitas Islam Lamongan

an.imfattach@gmail.com

\begin{abstract}
Abstrak Youth Creative Entrepreneur Empowerment (YoutivEE), program pemberdayaan kaum muda untuk berkontribusi pada perekonomian dan mengurangi pengangguran . YoutivEE merupakan sebuah program pemberdayaan yang dapat dilaksanakan oleh pemerintah, swasta atau bahkan para kaum muda sendiri. Dilihat dari Bali Sustainable Creative Industri Supply Chain, YoutivEE merupakan program yang diperuntukkan kepada para mahasiswa di universitas negeri maupun swasta. YoutivEE bertujuan untuk mempersiapkan mahasiswa dengan segala softskill dan hardskill sebelum terjun di industri kreatif dan nantinya dapat berkontribusi dalam memberdayakan masyakat sekitar. YoutivEE bersifat berkesinambungan, YoutivEE di tingkat universitas akan dilanjutkan YoutivEE di tingkat kota (city based). YoutivEE akan dibina langsung oleh orang yang telah berpengalaman di bidangnya dan dimentor secara khusus langkah demi langkah
\end{abstract}

Kata Kunci Kaum Muda, Industri Kreatif, Pengangguran. YoutivEE 


\section{PENDAHULUAN}

Pengangguran berpendidikan merupakan permasalahan besar di Indonesia,berdasarkan data statistik pengangguran lulusan Diploma/Akademisi tahun 2013, sekitar 322.836 jiwa (pemuda 138.749 dan pemudi 184.087). Sedangkan, sarjana lulusan universitas sekitar 385.418 jiwa (pemuda 184.497 dan pemud 200.921), bila ditotal terdapat sekitar 708.254 jiwa pengangguran dari kalangan sarjana muda (Departemen Tenaga Kerja dan Transmigrasi Republik Indonesia, 2013). Orang terdidik, yang di wakili oleh para lulusan perguruan tinggi seharusnya tidak hanya memiliki kemampuan hard skill saja, sebab kontradiksi dengan kondisi para pengangguran usia muda, di Indonesia juga terdapat para anak muda yang dapat dengan sukses memulai dan mempertahankan bisnisnya.

YoutivEE akan dilaksanakan dua tahap yaitu university based dan city based. University based lebih fokus pada pengembangan dan pendidikan mahasiswa yang ada di universitas dan dipersiapkan untuk terjun di industri kreatif. Sedangkan pada

YoutivEE city based, para mahasiswa yang telah dibekali di university YoutivEE dapat memberdayakan masyarakat sekitar. YoutivEE, apabila dilaksanakan dan didukung oleh seluruh kalangan, maka akan bermanfaat secara jangka panjang dan dapat membantu mengurangi pengangguran yang ada. Keberanian dalam bertindak

dan rela keluar dari zona nyaman merupakan kunci dari kesuksesan sebuah bangsa, dan ini dapat dimulai melalui program YoutivEE

\section{TINJAUAN TEORITIS}

\section{Urgensi Pengembangan Sumber Daya Manusia pada Mahasiswa}

Mahasiswa adalah individu pilihan yang diharapkan dapat berkontribusi di masyarakat, berkarakter paling dinamis dan paling berpengetahuan. Oleh karena itu, masyarakat harus memberi perhatian yang lebih dalam hal pengembangannya, memastikan lingkungan belajar yang layak, memberi guru dan dosen untuk mendidik dan mengamanahkan kepada mereka guru agama untuk memberi pendidikan agama di atas landasan aqidah yang memperhatikan aspek

jasmani, akal, ruhani, perasaan dan emosi. Oleh sebab itu kewajiban bagi mahasiswa untuk memberikan segenap pemikiran, ilmu dan amal hingga ia maju bersama masyarakat, dan masyarakat berbangga dengan keberadaannya. Mustafa Muhammad Thahan, (2001) merumuskan :

1. Kekuatan Mahasiswa

a. Mahasiswa adalah pemuda yang memiliki kemampuan, tekad, keberanian dan kesabaran menghadapi tantangan. Kemampuan ini lah yang tidakdimiliki oleh lapisan masyarakat lain.

b. Mahasiswa adalah Pemuda yang memiliki semangat belajar yang kuat, menguasai dan menghasilkan pemikiran serta pembaharuan. Ibarat ranting yang masih segar, 
kelenturannya cukup untuk terbentuknya pemikiran sekaligus mentransformasikan pemikiran tersebut kepada orang lain

c. Mahasiswa memiliki keimanan dan akhlak pemuda selalu memunculkan energi terbesar dalam bentuk gerakan membina masyarakat.

d. Mahasiswa adalah pemuda adalah pelopor dan sarana perubahan, pemuda memiliki kekuatan jiwa yang besar maka perubahan yang dilakukan pun besar.

2. Mahasiswa dapat memberi tanpa berpihak/Obyektif

Mahasiswa yang berwawasan luas dan mempunyai pengalaman masa lalu, mengambangkan aktivitas masa kini secara dinamis, ditambah kemampuan mengembangkan diri serta memandang jauh ke masa depan yang cemerlang, mereka akan bersikap objektif dan positif, jauh dari hal-hal yang memecah belah barisan dan pemikiran mereka.

\section{Gambaran Ekonomi Kreatif di Indonesia}

Departemen Perdagangan dalam Buku Pengembangn Industri Kreatif Menuju Visi Ekonomi Kreatif 2025 (2009) secara rinci menggambarkan 14 subsektor industry kreatif yang ada di Indonesia :

1. Musik

Industri Kreatif sub sektor musik adalah kegiatan kreatif yang berkaitan dengan kreasi/komposisi, pertunjukan musik, reproduksi, dan distribusi dari rekaman suara. Seiring dengan perkembangan industri music ini yang tumbuh sedemikian pesatnya, maka Klasifikasi Baku Lapangan Indonesia 2005 (KBLI) perlu dikaji ulang, yaitu terkait dengan pemisahan lapangan usaha distribusi reproduksi media rekaman, manajemen-representasi promosi (agensi) musik, jasa komposer, jasa pencipta lagu dan jasa penyanyi menjadi suatu kelompok lapangan usaha sendiri.

\section{Periklanan}

Subsektor industri periklanan dapat didefinisikan sebagai industri jasa yang mengemas bentuk komunikasi tentang suatu produk, jasa, ide, bentuk promosi, informasi: layanan masyarakat, individu maupun organisasi yang diminta oleh pemasang iklan (individu, organisasi swasta/pemerintah) melalui media tertentu (misal: televisi, radio, cetak, digital signage, internet) yang bertujuan untuk mempengaruhi, membujuk target individu/masyarakat untuk membeli, mendukung atau sepakat atas hal yang ingin dikomunikasikan.

\section{Arsitektur}

Subsektor arsitektur, arsitektur didefinisikan sebagai wujud hasil penerapan pengetahuan, ilmu, teknologi, dan seni secara utuh dalam menggubah ruang dan lingkungan binaan, sebagai bagian dari kebudayaan dan peradaban manusia, sehingga dapat menyatu dengan keseluruhan lingkungan ruang dari tingkat makro sampai dengan tingkat mikro. Pada skala makro, arsitektur berkaitan dengan perencanaan tata kota (town planning, urban/rural planning), landscape 
planning, urban design hingga perencanaan transportasi. Sedangkan dalam skala mikro dimulai dari perencanaan interior ruangan hingga bangunan termasuk eksterior maupun taman.

4. Film dan Video

Industri Kreatif Subsektor film, video, dan fotografi adalah kegiatan kreatif yang terkait dengan kreasi, produksi video, film, dan jasa fotografi, serta distribusi rekaman video, film dan hasil fotografi. Termasuk di dalamnya penulisan skrip, dubbing film, sinematografi, sinetron, dan eksibisi film.

\section{TV dan Radio}

Industri Kreatif kelompok televisi dan radio meliputi kegiatan kreatif yang berkaitan dengan usaha kreasi, produksi dan pengemasan, penyiaran, dan transmisi televisi dan radio.

6. Fesyen

Industri Kreatif Subsektor fesyen/mode adalah kegiatan kreatif yang terkait dengan kreasi desain pakaian, desain alas kaki, dan desain aksesoris mode lainnya, produksi pakaian mode dan aksesorisnya, konsultansi lini produk fesyen, serta distribusi produk fesyen.

7. Layanan Komputer dan Perangkat Lunak

Industri Kreatif sub sektor layanan komputer dan piranti lunak meliputi kegiatan kreatif yang terkait dengan pengembangan teknologi informasi termasuk jasa layanan komputer, pengembangan piranti lunak, integrasi sistem, desain dan analisis sistem, desain arsitektur piranti lunak, desain prasarana piranti lunak dan piranti keras, serta desain portal.

Menurut Depperin, industri software meliputi aplikasi Internet, aplikasi web, software bisnis, kreatif, dan sains. Sementara konten mencakup e-content, business intelligence, iklan, customer service, games, animasi, berita, edukasi dan lainnya.

\section{METODE PENELITIAN}

Penelitian ini fokus pada pembahasan mengenai inisiasi program pemberdayaan mahasiswa, Youth Creative Entrepreneur Empowerment. Sesuai dengan rumusan masalah, penelitian ini menggunakan penelitian deskriptif kualitatif. Riset kualitatif memroses pencarian gambaran data dari konteks kejadiaanya langsung, sebagai upaya melukiskan peristiwa sepersis kenyataanya, yang berarti membuat pelbagai kejadiannya seperti merekat, dan melibatkan perspektif (peneliti) yang partisipatid di dalam pelbagai kejadiannya, serta menggunakan penginduksian dalam menjelaskan gambaran fenomena yang diamatinya (Gorman \& Clayton dalam Santana : $2007: 30$ ).

Penelitian ini bermaksud untuk menggambarkan secara kualitatif program pemberdayaan mahasiswa Youth Creative Entrepreneur Empowerment dengan terlebih dahulu peneliti mencari gambaran gambaran fakta terkait permasalahan yang dimaksud, lalu peneliti menggambarkan fenomena yang diamatinya lalu selanjutnya memberikan tawaran sebuah program yang dapat membantu menyelesaikan fenomena yang ada. (2009). Peneliti mengambil contoh Universitas 
Islam Lamongan dalam pengimplementasian konsep Youtivee dan memproyeksikan pelaksanaan program tersebut.

\section{Jenis Data dan Metode Pengumpulan Data}

\section{Jenis Data}

Data merupakan kumpulan fakta-fakta yang diyakini kebenarannya, yang dihasilkan dari pengamatan, pengukuran, atau pencacahan karakteristik obyek. (McLeod dalam Noor, 2009). Data yang dikumpulkan dalam penelitian ini adalah sekunder, yaitu sumber data penelitian yang diperoleh secara tidak langsung melalui media perantara atau diperoleh dan dicatat oleh pihak lain, seperti : data statistik, buku, majalah, internet, dan jurnal.

\section{Metode Pengumpulan Data}

Metode pengumpulan data yang digunakan didalam penelitian ini adalah dengan metode:

1.Studi literatur

Studi literatur adalah penelitian dengan jalan menelusuri literatur yang ada serta menelaahnya secara tekun. Literatur yang ada berkaitan serta menunjang penelitian penelitian ini, baik berupa pustaka cetak maupun elektronik.

\section{Diskusi}

Diskusi adalah cara pengumpulan data dengan melakukan pembicaraan dan bertukar pikiran dengan orang-orang atau kelompok, kemudian membahas masalah-masalah yang muncul guna memecahkan masalah tertentu. Peneliti melakukan diskusi dengan beberapa tokoh antara lain Prof. Djumilah Zein, Guru Besar Ilmu Manajemen Usaha Kecil Fakultas Ekonomi Universitas Brawijaya dan Togar M. Simatupang, Ph.D, pakar ekonomi kreatif Indonesia dari SBM ITB Bandung.

\section{Dokumentasi}

Dokumentasi berupa membaca laporan-laporan penelitian sebelumnya serta artikel yang diakses dari internet. Penulis hanya memindahkan data yang relevan dari suatu sumber atau dokumen yang diperlukan.

\section{Metode Analisis Data}

Penelitian ini menggunakan teknik analisis data deskriptif. Dari data-data yang diperoleh kemudian disusun berdasarakan aturan dan analisis sehingga mempermudah pembahasan masalah-masalah yang ada. Dengan metode ini, peneliti ingin mengungkap keadaaan pengangguran pada kaum muda dan industry kreatif di Indonesia dan menganalisis potensipotensi yang dapat dikembangkan para kaum muda untuk terjun di sektor ekonomi kreatif. Proses analisa data dalam penelitian ini terjadi dalam empat jalur kegiatan yang terjadi secara bersamaan yaitu (Miles dan Huberman dalam Noor, 2009) :

1. Pengumpulan data (data collection)

2. Reduksi data (data reduction)

3. Penyajian data (data display)

4. Penarikan kesimpulan dan verifikasi 


\section{PEMBAHASAN}

Sektor Ekonomi Kreatif : Peluang dan Tantangan

Ekonomi kreatif, sektor ekonomi yang bertumpu pada kekayaan intelektual dan kreatifitas manusia merupakan sebuah peluang besar bagi perekonomian Indonesia. Jikalau saja permintaan domestik Indonesia akan industri kreatif dapat dipenuhi oleh masyarakat Indonesia sendiri, maka akan semakin tinggi kontribusi industri kreatif terhadap PDB Indonesia, dari yang sebelumnya hanya $4.7 \%$ persen saja. Masyarakat Indonesia adalah pasar yang sangat besar bagi industri kreatif seluruh 14 subsektor industri kreatif merupakan peluang bagi kaum muda untuk terjun menjadi creative entrepreneur, hal ini dikarenakan industri kreatif memang membutuhkan sumber daya yang berjiwa muda, bermodalkan kreatifitas dan penuh dengan inovasi. Berbicara mengenai kekayaan budaya Indonesia yang menjadi salah satu peninggalan harta kreatifitas juga tidak ada habisnya, kita memiliki Indonesia yang memiliki ragam budaya, ciri khas kota dan budaya masyarakatnya, seluruh kekuatan ini, jikalau dikemas dengan kreatifitas meruapakn peluang besar bagi kaum muda dalam mengatasi pengangguran. Selain menggunakan kekayaan local, kekayaan intelektual, kreatifitas dan keberanian anak muda dalam mengexplorasi karya juga merupakan kekuatan tersendiri, karakter kaum muda yang senang berkumpul juga dapat dijadikan komunitas yang dapat digunakan pasar yang potensial.

\section{Industrial Economy Structure}

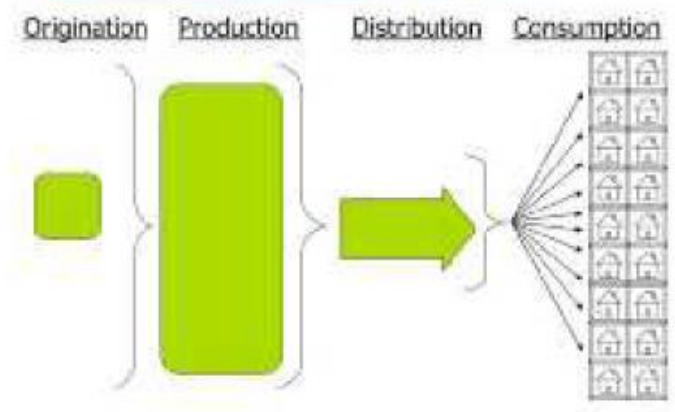

\section{Creative Industry Structure}

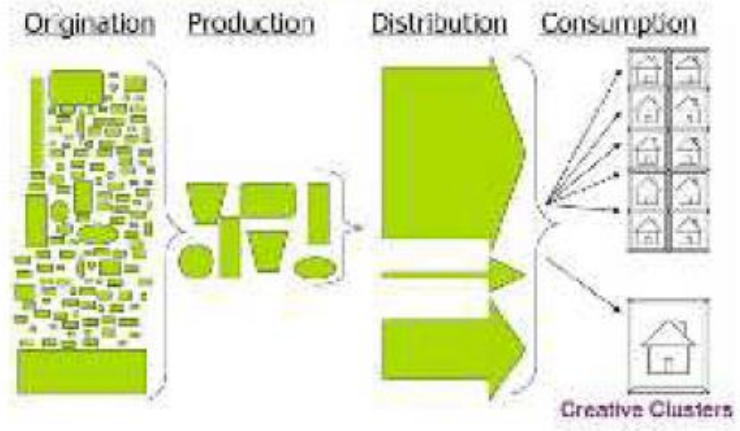

Gambar 4.1 Struktur industri kreatif yang memberdayakan (ideonomics.com)

Tantangan yang ada saat ini dalam pengembangan ekonomi kreatif adalah bagaimana menyiapkan sumber daya manusia yang dapat total dan terjun di ekonomi kreatif. Dukungan pemerintah telah disusun dalam cetak biru pengembangan ekonomi kreatif dengan target pencapaian 2025. Seluruh komponen harus terintegrasi dalam sebuah program yang memiliki satu tujuan yang memiliki multiplier effect, mengatasi pengangguran dan memberikan kontribusi ekonomi. 


\section{Youth Creative Entrepreneur Empowerment (YoutivEE), Program Pemberdayaan Kaum Muda Untuk Berkontribusi Pada Perekonomian Dan Mengurangi Pengangguran}

Program Youth Creative Entrepreneur Empowerment, (YoutivEE) merupakan sebuah program pemberdayaan yang dapat dilaksanakan oleh pemerintah, swasta atau bahkan para kaum muda sendiri. Dilihat dari Bali Sustainable Creative Industri Supply Chain, proses penginternalan jiwa wirausaha kreatif ada dalam idea generator.

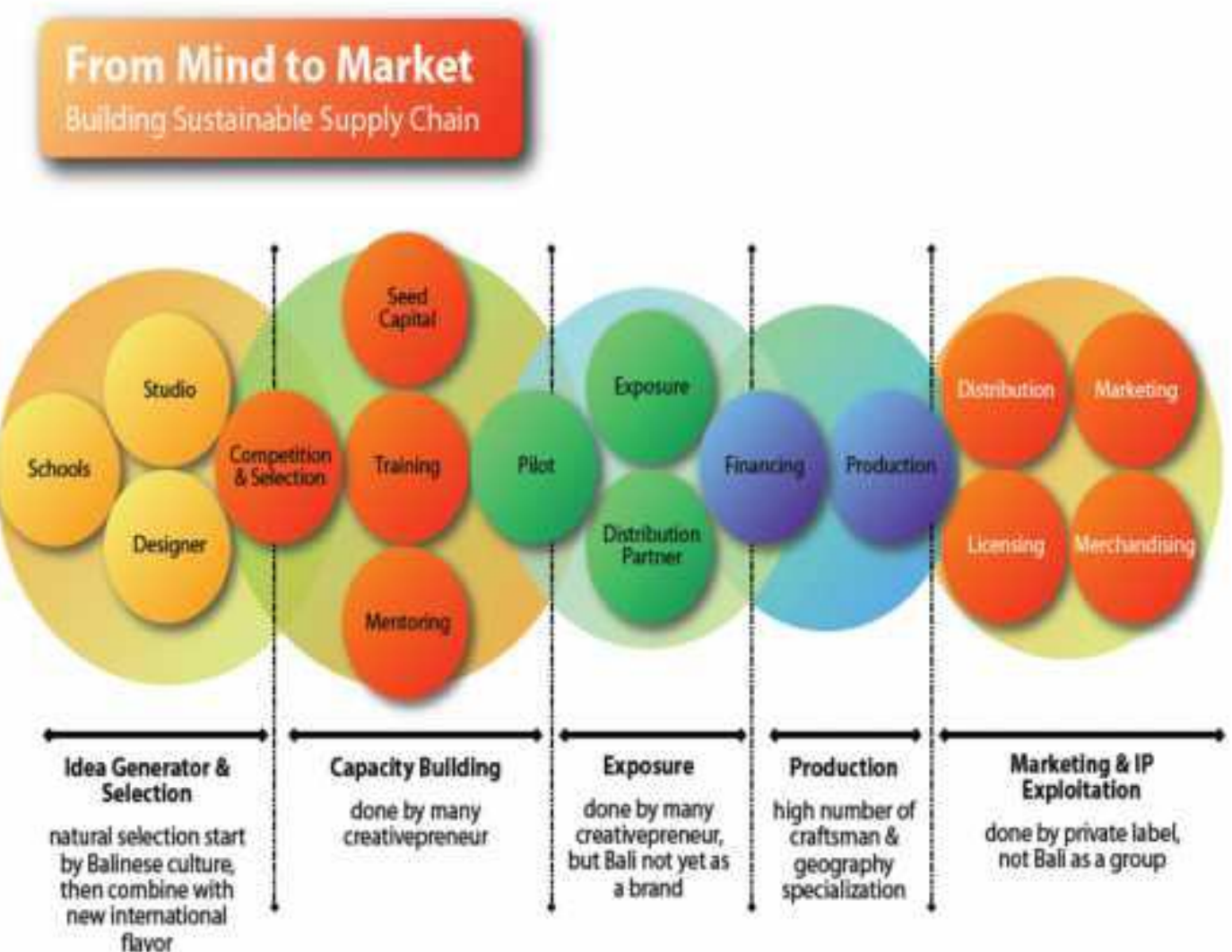

Hal ini merupakan sebuah rangkaian jangka panjang dan berkesinambungan. YoutivEE diperuntukkan kepada para mahasiswa di universitas negeri maupun swasta, YoutivEE bertujuan untuk mempersiapkan mahasiswa dengan segala softskill dan hardskill sebelum terjun di industri kreatif dan nantinya memberdayakan masyarakat sekitar. YoutivEE bersifat berkesinambungan dimana YoutivEE di tingkat universitas akan dilanjutkan YoutivEE di tingkat kota (city based). YoutivEE akan dibina langsung oleh orang yang telah berpengalaman di bidangnya dan dimentor secara khusus langkah demi 
langkah.

Youth Creative Entrepreneur Empowerment (YoutivEE) sebuah konsep umum.

Youth Creative Entrepreneur Empowerment (YoutivEE) adalah sebuah program inisasi penulis yang penulis rekomendasikan untuk diaplikasikan di perguruan tinggi Indonesia, hal ini dikarenakan dengan perguruan tinggi merupakan sebuah rantai yang berkaitan dengan sector industi kreatif Indonesia. Proses pelembagaan pemberdayaan wirausaha kreatif anak muda dikarenakan sesuatu yang sudah baku dan terstandardisasi akan efektif dan efisien dan pengembangan kelembagaannya dapat direncanakan secara jangka panjang. Proses pelembagaan Youth Creative Entrepreneur Empowerment (YoutivEE) di universitas juga dapat mempermudah para pendidik untuk mengukur keberhasilan mereka dalam mendidik.

Perguruan tinggi, pemerintah dan sector industry merupakan sektor yang saling berkaitan, pemerintah yang mendukung dengan kebijakan, perguruan tinggi menyiapkan sumber daya dan akademisi, dan sector industry atau swasta melaksanakan kegiatan ekonomi, oleh sebab itu pengembangan sumber daya manusia di perguruan tinggi haruslah memiliki sifat demand driven education, sehingga output yang ada tepat sasaran dan tepat guna. Penulis akan menyederhanakan konsep Youth Creative Entrepreneur Empowerment (YoutivEE) dalam sebuah contoh aplikatif, dengan mengambil contoh Universitas Islam Lamongan sebagai perguruan tinggi yang akan melaksanakan Youth Creative Entrepreneur Empowerment (YoutivEE). Dalam melaksanankan Youth Creative Entrepreneur Empowerment (YoutivEE) di universitas, maka kita terlebih dahulu harus memiliki strategi,berikut adalah proses yang harus ditempuh :

1. Melakukan proses analisis SWOT

2. Melakukan formulasi misi organisasi

3. Melakukan formulasi filosofi organisasi dan kebijakan

4. Menentukan tujuan strategis

5. Menentujan strategi organisasi

6. Implementasi dari strategi organisasi

7. Kontrol dari strategi organisasi

Universitas Islam Lamongan yang telah mencanangkan diri menjadi entrepreneurial university telah melakukan langkah awal dalam melakukan hal ini, opportunity dan threat yang terjadi akhir akhir ini dapat menjadi evaluasi kebijakan universitas untuk mendirikan sebuah lembaga pemberdaya mahasiswa yang bernama Youth Creative Entrepreneur Empowerment (YoutivEE )Center yang kemudian akan disebut YoutivEE Center.

Youtivee Center sarana Universitas Islam Lamongan untuk mengembangkan Young Creative Entrepreneur

Penginternalisasian sebuah nilai wirausaha kepada seluruh komponen universitas diperlukan sebuah lembaga yang bertanggung jawab dan terukur dalam melaksanakan tujuan tersebut, oleh sebab itu Youtivee Center didirikan, dengan visi Islamics Youtivee Center to be a leading creative empowerment basis in Indonesia, berikut adalah proses operasionalisasi organisasi IslamicsYoutivee Center 


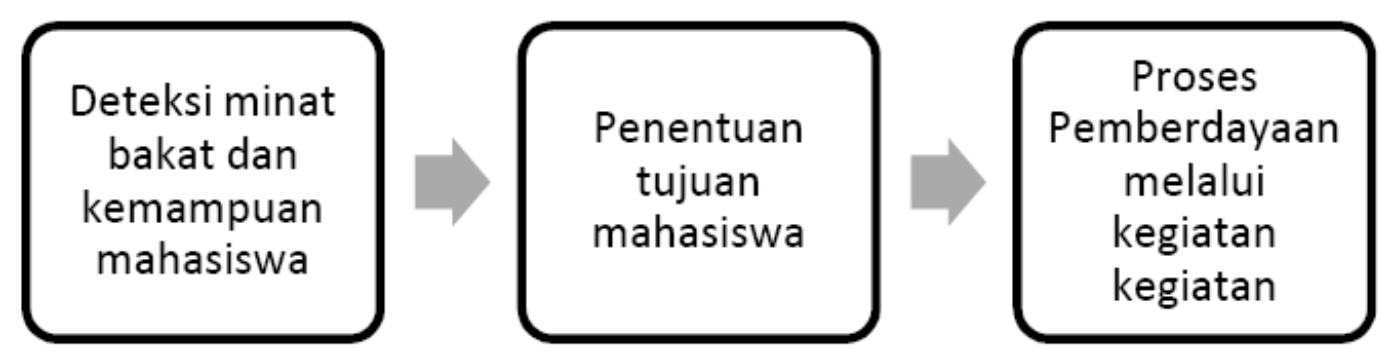

\section{Gambar 4.3 Operasionalisasi Youtivee Center}

Mahasiswa dibebaskan untuk memilih profesi output dari universitasnya sesuai dengan minat dan bakat mahasiswa, seluruh pilihan profesi diarahkan untuk mendekati demand pasar, sehingga proses pendidikan akan tepat guna, Kegiatan kegiatan yang dapat dilaksanakan antara lain :

1. Pelatihan kemampuan softskill

2. Magang langsung di industry

3. Bazaar produk hasil kreativitas mahasiswa

4. Pemberian dana oleh universitas melalui Studi Kelayakan Bisnis

5. Pengintensifikasian lembaga riset mahasiswa

6. Pelaksanaan seminar seminar isu terbaru sebagai wacana pengembangan mahasiswa pada perubahan zaman

7. Mentoring langsung oleh praktisi

\section{Internalisasi jiwa creative entrepreneur dalam kegiatan kemahasiswaan mandiri}

Youth Creative Entrepreneur Empowerment (YoutivEE) juga dapat dilaksanakan secara oleh mahasiswa sendiri tanpa menunggu adanya sistem formal, contohnya adalah internalisasi jiwa creative entrepreneur di dalam kegiatan kegiatan kemahasiswaan mandiri yang dilaksanakan

mahasiswa dengan menggunakan lembaga lembaga kemahasiswaan yang ada. Hal ini dengan sederhana dapat memberikan efek yang secara parsial kepada mahasiswa yang mengikuti kegiatan ini. Isu Youth Creative Entrepreneur Empowerment (YoutivEE) menjadi tema khusus dalam seminar, pelatihan, diskusi umum, dan riset ilmiah dan kegiatan kegiatan lainnya.

\section{Outbox Thinking sebagai kemampuan mahasiswa}

Untuk menjadi wirausaha kreatif, kemampuan dalam bidang pendidikan saja belum cukup, dengan adanya peluang di dalam industry kreatif menyebabkan perubahan yang terjadi sangat cepat, oleh sebab itu, dalam Youtivee, para mahasiswa dibekali dengan kemampuan minor yang membuat kemampuan mayor menjadi peluang bisnis didalamnya. Contoh : Youtivee 
Global Trends Apa yang terjadi di belahan dunia lainnya dan mengimplementasikannya dengan berbagai penyesuaian merupakan sebuah peluang untuk sebuah bisnis,oleh sebab itu para mahasiswa dibekali dengan pengetahuan trend duniam Youtivee I.T Based Penguasaan teknologi informasi meruapakan sebuah keharusan bagi siapa saja yang ingin memiliki bisnis jangka panjang. I.T juga dapat mereduksi biaya, oleh sebab itu di dalam Youtivee, para mahasiswa dibekali dengan kemampuan I.T Youtivee Social Networking Demam dunia akan jejaring sosial atau social networking menjadikan bisnis dapat berjalan langsung kepada pelanggan dan partner bisnis yang kita miliki. Social networking dapat menjadi senjata agar bisnis yang dilakukan para mahasiswa lebih mudah dikenal masyarakat.

\section{Youtivee City Based sebagai tindak lanjut program}

Sebuah kota, seharusnya memiliki fokus industri kreatif, di bagian mana kota tersebut akan memposisikan diri nya dan produknya dari ke 14 produk dan jasa kreatif yang ada.

1. Bentuk: lembaga dibawah pemerintahan namun berbentuk bebas, tidak terikat pada birokrasi yang kuno dan berbelit-belit.

2. Tujuan : output university based dapat memberdayakan masyarakat umum.

3. Kegiatan : melakukan bantuan akan usaha usaha industri kreatif dalam hal distribusi.

4. Melakukan event unggulan kota tersebut, contohnya Festival Malang Kembali, Malang Arts Festival, Malang Indie Movie Festival dan lain lain.

5. Melakukan branding akan kota tersebut contohnya, bandung dengan ikon Bandung Creative City.

\section{Multiple Effect dari Program Youth Creative Entrepreneur Empowerment}

Adanya program YoutivEE akan memberikan manfaat yang

berkesinambungan dan jangka panjang. Manfaat tersebut antara lain :

1. Menimbulkan kemandirian

Program YoutivEE akan merubah mindset para mahasiswa sejak di bangku kuliah sehingga para mahasiswa akan memilik tujuan yang jelas akan proses kuliah yang mereka jalani

2. Membantu mengurangi pengangguran

Program YoutivEE memang bukan merupakan satu-satunya solusi yang dapat menyelesaikan permasalahan pengangguran, baik itu dikalangan sarjana maupun non pendidikan, namun program YoutivEE akan membantu mengurangi pengangguran dari sarjana yang berwirausaha di industri kreatif dan juga para pekerja yang diberdayakan di dalamnya

3. Membantu menggerakkan sektor riil perekonomian

Program YoutivEE akan menggerakkan sektor ekonomi rill dimana barang dan jasa akan berputar, karena industri kreatif kebanyakan berbentuk usaha kecil dan menengah, maka industri kreatif ini akan banyak menopang sektor ekonomi masyarakat dimana banyak yang akan terlibat mulai dari produksi hingga distribusi.

\section{KESIMPULAN DAN SARAN}

Pengangguran sarjana sebagai permasalahan yang menahun harus diupayakan untuk dicari pemecahannya, memang hal ini sulit dipecahkan sebab melimpahnya sumber daya manusia di 
Indonesia yang memiliki pendidikan tinggi namun tidak memiliki pekerjaan ditambah sumber daya tidak berpendidikan namun tidak bekerja. Permasalahan ini dapat dikurangi dengan ikut sertanya para sarjana pada sektor industri kreatif, sektor yang sangat cocok pada karakter anak muda, kreatif, pemberani dan menyukai tantangan.

Peluang dari sektor ekonomi kreatif beserta 14 sub sektornya merupakan peluang besar yang dapat ditangkap dan dikembangkan. Kekayaan intelektual dan kreativitas pribadi mahasiswa diperkuat dengan kekayaan budaya Indonesia yang melimpah menjadikan hal ini menjadi kekuatan dan penting untuk segera dilakukan. Youth Creative Entrepreneur Empowerment, program yang direncanakan khusus untuk mempersiapkan sumber daya manusia untuk terjun disektor industry kreatif menjadi salah satu solusi yang dapat mengurangi pengangguran dan menjadikan para pemuda Indonesia memiliki kontribusi pada perekonomian. Youth Creative Entrepreneur Empowerment (YoutivEE) dapat dilaksanakan disemua universitas di Indonesia, peneliti mengambil contoh pada Universitas islam lamongan, visi universitas untuk menjadi entrepreneurial university menjadi dasar yang kuat untuk melaksanakan Youth Creative Entrepreneur Empowerment (YoutivEE). Berdasarkan penelitian deskriptif kualitatif peneliti merekomendasikan program ini untuk dilaksanakan di tataran perguruan tinggi Indonesia

\section{Saran}

Saran-saran yang dapat penulis berikan antara lain :

1. Para mahasiswa, hendaknya menyadari bahwa belajar di perguruan tinggi merupakan tanggung jawab yang besar sebab masa depan Indonesia ke depan ada di tangan para generasi muda. Oleh sebab itu, dengan ikut nya para mahasiswa dengan program Youtivee ini diharapkan dapat member kontribusi bagi pembangunan bangsa Indonesia.

2. Perguruan tinggi sehendaknya sudah mulai berpikir outbox thinking dalam mendidik mahasiswa, memberikan support dan penghargaan pada mahasiswa untuk berwirausaha.

3. Pemerintah hendaknya memberikan perhatian pada pengembangan sumber daya manusia kaum muda yaitu pada mahasiswa.

\section{Daftar Pustaka}

Afiansyah, Sofi A. 2009 Laporan Utama Industri Kreatif Majalah Indikator Nomor 44 Tahun XXII 2008

Afriani, Iyan H.S.2009. Metode Penelitian Kualitatif. http://www.penalaranunm.lorg/index.php/component/comprofiler/?task=userProfile\&use r=62diakses pada 12 Desember 2017

Irwansyah. 12 Nov 2008 Kalangan Muda Masuk Industri

Kreatif http://www.wartaekonomi.co.id 
Kusnadi, 2009. Sarjana dan Tingkat Sarjana dan Tingkat

Pengangguran. http://www.uniat.ac.id/?pilih=news\&mod=yes\&aksi=lihat\&id=4 diakses pada 12 Desember 2017

M. Noor Amrullah , 2009. Implikasi Penerapan Electronic Governmnet pada Pemerintah Kota Malang dalam Upaya Mewujudkan Good Governance. Skripsi Fakultas Ekonomi Universitas Brawijaya Malang.

Muhammad, Musthafa Thahan. 2002. Risalah Pergerakan Pemuda Islam. Jakarta Visi Publishing

Redaksi. 2008. Pendirian UKM Rekrut Pengangguran Dana Bergulir Se-Jatim Rp 9,6 Miliar. http://www.surya.co.id/. diakses pada 12 Desember 2017.

,8 Agustus 2008.Industri Kreatif Serap 5 Juta

Tenaga Kerja http://www.TempoInteraktif.com diakses pada 11 Desember2017.

,Industri Kreatif Yang Semakin Menjanjikan Majalah Swa edisi 23/XXIII/25

Oktober-7 Novemeber 2008. diakses 11 Desember 2017.

,Indeks Pembangunan Manusia. http://www.Wikipedia.com diakses pada

12 Desember 2017.

,Mendag: Industri Kreatif Potensi Besar Ekonomi Indonesia

http://www.analisadaily.com. diakses pada 12 Desember 2017.

,21 May 2008. Sisi Lain Industri Kreatif. http://www.kompascetak.com.

, 26 May 2008. Menkominfo: Industri Kreatif Dapat Tingkatkan Perekonomian

Negara. http://www.kapanlagi.com. diakses pada 12 Desember 2017.

, 2009.Kadin Akan Luncurkan Roadmap Industri Kreatif. http://www.antara.com. diakses pada 12 Desember 2017.

,Dec 2008 .Presiden Canangkan Tahun Indonesia Kreatif

http://www.presidensby.info. diakses pada 12 Desember 2017.

Publikasi Sidang Istimewa Kongres Mahasiswa ITB.2007. Konsepsi Organisasi Kemahasiswaan Keluarga Mahasiswa ITB . www. itb.ac.id diakses 12 Desember 2017 
Septiawan Santana K. 2007. Menulis Ilmiah Metode Penelitian Kualitatif. Jakarta : Yayasan Obor Indonesia.

Singgih BS, 26 May 2008 Produk Budaya Indonesia, Penggerak Ekonomi Rakyat Sumber : http://www.suarakarya-online.com. diakses pada 12 Desember 2017.

Simatupang,Togar M. Perkembangan Industri Kreatif. www.slideshare.net. diakses pada 12 Desember 2017.

Siregar, Oloan.Menghadapi Krisis Global Industri Kreatif Sakti Mandra Guna http://www. Beritasore.com

Zaenudin, Lutfi. Rabu, 24/10/2007.Industri kreatif makin prospektif http://www.BisnisIndonesia.com 